\title{
PENERAPAN SUPERVISI KLINIS OLEH KEPALA SEKOLAH SEBAGAI UPAYA MENINGKATKAN KEMAMPUAN GURU MENGGUNAKAN MODEL PEMBELAJARAN KOOPERATIF DI SEKOLAH DASAR INPRES TARAWAJA SEMESTER GANJIL TAHUN 2018/2019
}

\author{
Petronela Bupu \\ Kepala Sekolah Dasar Inpres Tarawaja, Kecamatan Soa
}

\begin{abstract}
Penelitian ini bertujuan untuk meningkatkan kemampuan guru dalam menggunakan model pembelajaran kooperatif di SDI Tarawaja, Kecamatan Soa. Jenis penelitian yang digunakan adalah penelitian tindakan sekolah. Kegiatan dalam penelitian ini terdiri atas tahapan perencanaan tindakan, pelaksanaan tindakan, observasi, dan refleksi. Penelitian ini dilakukan dalam dua siklus. Tempat penelitian di SDI Tarawaja, Kecamatan Soa, Kabupaten Ngada. Subyek dalam penelitian ini adalah guru-guru di SDI Tarawaja yang berjumlah 8 orang, yang terdiri dari 6 orang guru kelas dan 2 orang guru mata pelajaran. Metode pengumpulan data menggunakan metode obeservasi kelas. Analisis data yang digunakan adalah teknik analisis deskriptif komparatif. Data kuantitatif yang diperoleh dideskripsikan dalam bentuk kata-kata atau penjelasan. Selanjutnya dilakukan komparasi data untuk memastikan ada tidaknya peningkatan kinerja guru dalam pelaksanaan pembelajaran di Kelas. Hasil penelitian diketahui pada kondisi awal nilai supervise klinis kepala sekolah dalam kegiatan pembelajaran diperoleh rata-rata 69,81 , pada Siklus I mengalami peningkatan dengan rata-rata peroleh nilai pada supervise klinis sebesar 76,92 mengalami peningkatan sebesar 7,11. Pada siklus II nilai supervise klinis diperoleh rata-rata 83,08. Mengalami peningkatan dari siklus I ke Siklus II sebesar 6 , 16. Dari data ini berarti terjadi peningkatan nilai supervise klinis kepala sekolah dalam kegiatan pembelajaran dari kondisi awal hingga akhir siklus II sebesar 13, 93\%. Hal ini dapat disimpulkan bahwa dengan Penerapan Supervisi Klinis Oleh Kepala Sekolah dapat Meningkatkan Kemampuan Guru Menggunakan Model Pembelajaran Kooperatif di Sekolah Dasar Inpres Tarawaja semester Ganjil Tahun 2018/2019
\end{abstract}

Kata kunci: Supervisi Klinis, Kemampuan Guru, Model Pembelajaran Kooperatif

\begin{abstract}
This study aims to improve the ability of the teachers in using the cooperative learning models at elementary school of Tarawaja, Soa District. The type of this research is Action research. The activities in this study consisted of the stages of planning, action, observation, and reflection. This research has been conducted in two cycles. Research site at Tarawaja elementary school, Soa District, Ngada Regency. The subjects of this research were 8 teachers at Tarawaja elementary school, consisting of 6 class teachers and 2 subject teachers. The data collection method used the class observation method. The data Analysis is a comparative descriptive analysis technique. The quantitative data was obtained the described in the form of words or explanations. Then the data is compared to ensure there is an increasing in teacher performance in the implementation of learning in the classroom or nothing. The results of this research are known to the initial
\end{abstract}


condition of the clinical supervision value of the principal in learning activities obtained an average of 69.81, in Cycle I has increased with an average score on clinical supervision of 76.92 has increased by 7.11 . In cycle II clinical supervision values obtained an average of 83.08. There is an increasing from cycle I to cycle II of 6,16 . From this data means an increase in the value of clinical supervision of school principals in learning activities from the initial condition to the end of the second cycle of $13,93 \%$. It can be concluded that the Implementation of Clinical Supervision by the school head master could be Improved the Teacher's Ability in using the Cooperative Learning Model in Tarawaja Elementary School in the Odd Semesters of 2018/2019

\section{Keywords: Clinical Supervision, Teacher Ability, Cooperative Learning Model}

\section{PENDAHULUAN}

Keberhasilan kepala sekolah dalam melaksanakan tugasnya banyak ditentukan oleh kepemimpinan kepala sekolah. Kepemimpinan merupakan faktor yang paling penting dalam menunjang tercapainya tujuan organisasi sekolah. Keberhasilan kepala sekolah dalam mengelola kantor, mengelola sarana prasarana sekolah, membina guru, atau mengelola kegiatan sekolah lainnya banyak ditentukan oleh kepemimpinan kepala sekolah. Apabila kepala sekolah mampu mempengaruhi, menggerakkan, membimbing, dan mengarahkan anggota secara tepat, segala kegiatan yang ada dalam organisasi sekolah akan bisa terlaksana secara efektif. Sebaliknya, bila tidak bisa menggerakkan anggota secara efektif, tidak akan bisa mencapai tujuan secara optimal.

Dalam melaksanakan tugasnya kepala sekolah dituntut untuk selalu meningkatkan efektifitas kerja. Wahjosumidjo (2011:83) menyebutkan kepala sekolah dapat didefinisikan sebagai seorang tenaga profesional guru yang diberi tugas untuk memimpin suatu sekolah dimana diselenggarakan proses belajar mengajar. Sedangkan menurut Mulyasa (2007:126), kepemimpinan kepala sekolah yang efektif meliputi: (1) Mampu memberdayakan guru-guru untuk melaksanakan proses pembelajaran dengan baik, lancar, dan produktif. (2) Dapat menyelesaikan tugas dan pekerjaan sesuai dengan tenggat waktu yang telah ditetapkan. (3) Mampu menjalin hubungan yang harmonis dengan masyarakat sehingga dapat melibatkan mereka secara aktif dalam rangka mewujudkan tujuan sekolah dan pendidikan. (4) Berhasil menerapkan prinsip kepemimpinan yang sesuai dengan tingkat kedewasaan guru dan pegawai lain di sekolah. (5) Bekerja dengan tim manajemen. (6) Berhasil mewujudkan tujuan sekolah secara produktif sesuai dengan ketentuan yang telah ditetapkan. Seperti yang telah dikemukakan di atas, ada 
beberapa kepemimpinan kepala sekolah yang efektif yang harus diterapkan oleh kepala sekolah sesuai dengan situasi, kebutuhan, serta motivasi para guru dan staf.

Sebagai pemimpin pendidikan, kepala sekolah memiliki sejumlah tugas dan tanggung jawab yang cukup berat. Untuk bisa menjalankan fungsinya secara optimal, kepala sekolah perlu menerapkan gaya kepemimpinan yang tepat.

Fungsi dan tugas kepala sekolah dapat diakronimkan menjadi emanslime (education, manager, administrator, supervisor, leader, inovator, motivator dan entrepreneur). Peran tersebut dapat dilihat secara lebih rinci sebagai berikut; a) Peran sebagai educator, kepala sekolah berperan untuk mempengaruhi dan menggerakan dalam pembentukan karakter yang didasari nilai-nilai pendidik sebagai berikut:a) kemampuanmengajar/membimbing peserta, dan membimbing guru; b) Peran sebagai manager,kepala sekolah berperan untuk mempengaruhi dan menggerakan sumber daya untuk mencapai tujuan institusi secara efektif dan efisien yaitu memiliki kemampuan menyusun program sekolah, menyusun program serta mampu menggerakan warga sekolah; c) Peran sebagai administrator, kepala sekolah berperan dalam mempengaruhi dan menggerakan tata aksana sistem administrasi di sekolah sehingga efektif dan efisien yang meliputi memiliki kemampuan mengelola \begin{tabular}{ll} 
administrasi & \multicolumn{2}{c}{ pembelajaran, } \\
administrasi & peserta didik , \\
administrasi & ketenagaan, dan
\end{tabular} administrasi keuangan dan sarana prasarana; d) Peran sebagai supervisor, kepala sekolah berupaya membantu mengembangkan profesionalitas guru dan tenaga kependidikan lainnya. Kepala sekolah harus memiliki beberapa kemampuan sebagai berikut memiliki kemampuan menyusun program supervise pendidikan, melaksanakan program supervisi, dan memanfaatkan hasil supervisi.

Sebagai supervisor kepala sekolah melaksanakan tugasnya sesuai yang diamanatkan undangundang melalui Permendiknas nomor 15 tahun 2018 tentang Pemenuhan Beban Kerja Guru, Kepala Sekolah, dan Pengawas Sekolah yakni tugas merencanakan program supervisi guru dan tenaga kependidikan; b) melaksanakan supervisi guru; c) melaksanakan supervisi terhadap tenaga kependidikan; d) menindaklanjuti hasil supervisi terhadap Guru dalam rangka peningkatan profesionalisme Guru; e) melaksanakan Evaluasi Supervisi Guru dan Tenaga Kependidikan.

Supervisi yang dilakukan oleh kepala sekolah salah satunya adalah implementasi pembelajaran guru di dalam kelas atau pelaksanaan proses pembelajarn. Peningkatan kualitas pembelajaran salah satu faktor penentunya adalah peningkatan kualitas guru. Tenaga guru dituntut mampu 
\begin{tabular}{l}
\hline menunjukkan kompetensinya \\
sebagai guru yang profesional. \\
Mulyasa $(2003,45)$ mengemukakan \\
lima kompetensi dasar yang harus \\
dimiliki oleh seorang guru yang \\
profesional yaitu : (1) Penguasaan \\
kurikulum, (2) penguasaan materi \\
pelajaran, (3) penguasaan metode \\
dan tehnik evaluasi, (4) komitmen \\
terhadap tugas, dan (5) disiplin \\
dalam arti luas.
\end{tabular} Guru yang memiliki Kompetensi tinggi akan bersikap kreatif dan inovatif yang selamanya akan mencoba dan mencoba menerapkan berbagai penemuan baru yang dianggap lebih baik untuk pembelajaran siswa.Kompetensi guru bukan hanya dalam tataran desain perencanaan pembelajaran, akan tetapi juga dalam proses dan evaluasi pembelajaran. Dalam aspek perencanaan misalnya, guru dituntut untuk mampu mendesain perencanaan yang memungkins secara terbuka siswa dapat belajar sesuai dengan minat dan bakatnya., seperti Kompetensi merumuskan tujuan pembelajaran, Kompetensi menyusun dan menyajikan materi atau pengalaman belajar siswa, Kompetensi untuk merancang desian pembelajaran yang tepat sesuai dengan tujuan yang akan dicapai, Kompetensi menentukan dan memanfaatkan media dan sumber belajar, serta Kompetensi menentukan alat evaluasi yang tepat untuk mengukur keberhasilan proses pembelajaran. Kompetensi dalam proses pembelajaran berhubungan erat dengan bagaimaa cara guru
mengimplementasikan perencanaan pembelajaran, yang mencakup kompetensi menerapkan keterampilan dasar mengajar dan keterampilan mengembangkan berbagai model pembelajaran yang dianggap mutakhir.Sedangkan keterampilan mengembangkan model pembelajaran seperti keterampilan proses, model pembelajaran, metode klinis, dan pendekatan pembelajaran.

Salah satu pendekatan dalam proses pembelajaran adalah Pendekatan pembelajaran cooperative learning merupakan konsep belajar yang membantu guru mengaitkan antara materi yang diajarkan dengan situasi dunia nyata siswa dan mendorong siswa membuat hubungan antara pengetahuan yang dimilikinya dengan penerapannya dalam kehidupan mereka sebagai anggota keluarga dan masyarakat. Dengan konsep itu, hasil pembelajaran diharapkan lebih bermakna bagi siswa. Proses pembelajaran berlangsung alamiah dalam bentuk kegiatan siswa bekerja dan mengalami, bukan mentransfer pengetahuan dari guru ke siswa. Strategi pembelajaran lebih dipentingkan daripada hasil.

Dari hasil supervisi pembelajaran untuk 8 guru di SDI Tarawaja ditemukan $50 \%$ atau 4 orang guru yang belum kreatif menggunakan model pembelajaran maupun teknik pendekatan yang baru, akibatnya mutu pembelajaran menurun $(8,7 \%)$ 
atau 9 siswa yang tidak naik ketingkat berikutnya dari jumlah siswa seluruh 103 orang, pada akhir tahun pelajaran 2017/2018.

Selain itu ditemukan juga, guru dalam melaksanakan pembelajaran tanpa menggunakan RPP yang dibuat sendiri, mereka cenderung menggunakan RPP copy paste dan belum melaksanakan pembelajaran kooperatif. Guru masih melaksanakan pembelajaran dengan metode ceramah murni yang bersifat klasikal, belum maksimal menggunakan alat peraga, dan jarang melakukan pembelajaran yang kreatif seperti model pembelajaran kooperatif, yang dapat melatih mandiri dan tanggungjawab para peserta didik. Menurut Wilibaldus pembelajaran kooperatif menginginkan adanya perubahan dalam paradigma pembelajaran, yaitu dari paradigma mengajar menjadi paradigma belajar artinya siswa yang lebih aktif dalam proses pembelajaran. Dalam pembelajaran kooperatif Wilibaldus juga mengatakan bahwa siswa tidak hanya sebagai objek belajar tetapi menjadi subjek belajar karena mereka dapat berkreasi secara maksimal dalam proses pembelajaran.

Berdasarkan kondisi ini peneliti dalam pelaksanaan tugasnya adalah sebagai kepala sekolah berupaya agar semua guru dalam melaksanakan pembelajaran berpusat dengan model pembelajaran kooperatif, sesuai dengan ketentuan yang ada dalam Standar Proses dalam
Permendiknas nomor 22 tahun 2016. Ketentuan itu merupakan pedoman yang harus diwujudkan dalam proses pembelajaran oleh guru yang merupakan pimpinan di kelas itu. Apabila semua guru dalam melaksanakan tugasnya setiap hari mengajar dengan berpusat kooperatif di kelasnya, maka dapat dikatakan, bahwa hasil dari proses pembelajaran itu akan tercapai memuaskan, yang pada gilirannya akan meningkatkan prestasi belajar para peserta didiknya.

Dengan menggunakan model pembelajaran kooperatif diharapkan dapat mengatasi persioalan yang dihadapi diatas. Oleh Karena Itu Penulis Perlu Melakukan Penelitian Dengan Judul : Penerapan Supervisi Klinis Oleh Kepala Sekolah Sebagai Upaya Meningkatkan Kemampuan Guru Menggunakakan Model Pembelajaran Kooperatif Di Sekolah Dasar inpres Tarawaja semester Ganjil Tahun 2018/2019

Rumusan masalah yang digunakan adalah Apakah dengan menerapkan supervisi klinis oleh kepala sekolah dapat meningkatkan kemampuan guru menggunakan model pembelajaran kooperatif di Sekolah Dasar Inpres Tarawaja semester ganjil tahun 2018/2019? Sedangkan penelitian tindakan sekolah ini bertujuan untuk mengetahui peningkatan kemampuan guru menggunakan model pembelajaran kooperatif di Sekolah Dasar Inpres Tarawaja melalui supervisi klinis kepala 


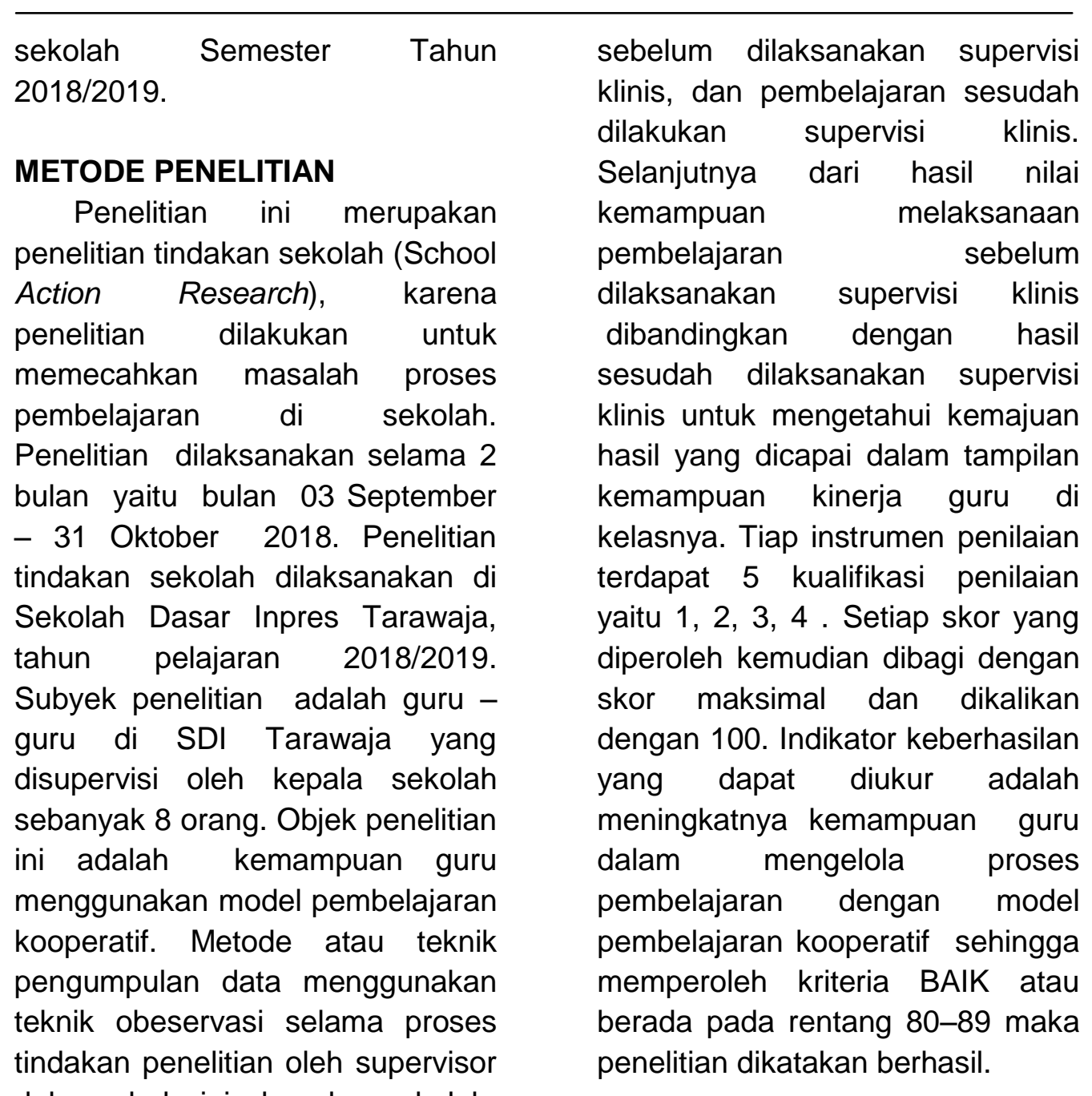
dalam hal ini kepala sekolah. Instrument yang digunakan adalah pedoman observasi. Instrumen observasi yang digunakan berupa alat penilaian kompetensi guru (APKG) dalam pelaksanaan Pembelajaran yang terdiri dari Pedoman Observasi Penilaian Rencana Pelaksanaan Pembelajaran ( RPP) dan Pedoman Observasi Penilaian Pelaksanaan Pembelajaran

Analisis data yang digunakan peneliti dengan menggunakan analisis deskriptif komparatif, yaitu dengan membandingkan pelaksanaan pembelajaran

\section{HASIL DAN PEMBAHASAN}

Dalam penelitian ini penggunaan supervise klinis dapat meningkatkan kemampuan guru dalam menggunakan model pembelajaran kooperatif di SDI Tarawaja, Kecamatan Soa, Kabuaten Ngada.

Berdasarkan hasil tindakan pada siklus I dan II di atas dapat dirangkum ke dalam tabel 1.0 berikut ini yaitu dari data awal, siklus 1, dan siklus 2. Pada mutu pembelajaran terjadi peningkatan dari data awal sampai akhir siklus II: 


\begin{tabular}{lcc}
\hline \multicolumn{3}{c}{ Tabel 1.0 Nilai Sepervisi Klinis Siklus I dan Siklus II } \\
\hline \multicolumn{1}{c}{ Kegiatan } & Nilai & Peningkatan \\
\hline Kondisi Awal & 69,81 & - \\
Siklus I & 76,92 & 7,11 \\
Siklus II & 83,08 & 6,16 \\
Rata - Rata peningkatan & & $13,93 \%$ \\
\hline
\end{tabular}

Dari tabel di atas dapat diketahui pada kondisi awal nilai supervise klinis kepala sekolah dalam kegiatan pembelajaran diperoleh rata-rata 69,81 , pada Siklus I mengalamai peningkatan dengan rata - rata peroleh nilai pada supervise klinis sebesar 76,92 mengalami peningkatan sebesar 7,11 . Pada siklus II nilai supervise klinis diperoleh rata rata 83,08. Mengalami peningkatan dari siklus I ke Siklus II sebesar 6, 16. Dari data ini berarti terjadi peningkatan nilai supervise klinis kepala sekolah dalam kegiatan pembelajaran dari kondisi awal hingga akir siklus II sebesar 13, 93\%. Berdasarkan data tersebut dapat dilakukan pembahasan bahwa Penelitian Tindakan Sekolah tentang peneraan supervisi klinis oleh kepala sekolah sebagai upaya meningkatkan kemampuan guru dalam menggunakan model pembelajaran kooperatif di SDI Tarawaja dapat dikatakan berhasil karena terjadi peningkatan skor pada mutu pembelajaran. Hal ini lebih terlihat jelas pada tabel di atas. Walaupun masih belum sempurna, namun sudah mendekati pada skor maksimal dalam arti ada peningkatan yang memuaskan.
Penerapan supervise klinis dapat meningkatkan kemampuan guru dalam menggunakan model pembelajaran. Model pembelajaran yang diambil dalam penelitian ini adalah model pembelajarn kooperatif. Guru yang memiliki Kompetensi tinggi akan bersikap kreatif dan inovatif yang selamanya akan mencoba dan mencoba menerapkan berbagai penemuan baru yang dianggap lebih baik untuk pembelajaran siswa. Kompetensi dalam proses pembelajaran berhubungan erat dengan bagaimaa cara guru mengimplementasikan

perencanaan pembelajaran, yang mencakup kompetensi menerapkan keterampilan dasar mengajar dan keterampilan mengembangkan berbagai model pembelajaran yang dianggap mutakhir.Sedangkan keterampilan mengembangkan model pembelajaran seperti keterampilan proses, model pembelajaran, metode klinis, dan pendekatan pembelajaran.

Salah satu pendekatan dalam proses pembelajaran adalah Pendekatan pembelajaran cooperatif learning merupakan konsep belajar yang membantu guru mengaitkan antara materi yang diajarkan dengan situasi dunia nyata siswa dan mendorong 
siswa membuat hubungan antara pengetahuan yang dimilikinya dengan penerapannya dalam kehidupan mereka sebagai anggota keluarga dan masyarakat.

$$
\text { Keith Acheson dan }
$$

Meredith D. Gall menyatakan bahwa supervisi klinis adalah proses membantu guru memperkecil kesenjangan antara tingkah laku mengajar yang nyata dengan tingkah laku yang ideal (Ngalim Purwanto: 2006). Pelaksanaan supervise dapat dilakukan oleh kepala sekolah. Soetjipto dan Kosasi (2009:249) menjelaskan lima langkah atau tahap dalam supervisi klinis yaitu pembicaraan pra observasi, melaksanakan observasi, melakukan analisis dan menentukan strategi, melakukan pembicaraan tentang hasil supervisi, dan melakukan analisis setelah pembicaraan. Dalam melaksanakan supervisinya, kepala sekolah berupaya menyediakan kondisi kerja yang terbuka supaya masalah yang akan dipecahkan diketahui terlebih dahulu. Pemahamannya tentang supervisi bukan saja harus menyediakan waktu untuk melakukan kunjungan ke dalam kelas untuk melakukan observasi dan mengikuti berbagai pertemuan, melainkan juga meliputi penyediaan kondisi kerja yang menguntungkan dan memberi kemudahan pada guru-guru dalam melaksanakan tugasnya.

Berdasarkan uraian di atas, dan sesuai dengan teori - teori pendukung serta kajian hasil - hasil penelitian yang relevan yang diambil sebagai refrensi dalam penelitian ini terbukti bahwa penerapan supervise klinis dapat meningkarkan kemampuan guru menggunakan model pembelajaran kooperatif di SDI Tarawaja, Kecamatan Soa, Kabupaten Ngada Tahun pelajaran 2018/2019.

\section{SIMPULAN DAN SARAN}

Supervisi klinis dapat meningkatkan pemahanan dan kemampuan guru dalam menggunakan model pembelajaran kooperatif di SDI Tarawaja, Kecamatan Soa, Kabupaten Ngada, tahun pelajaran 2018/2019, terbukti dengan hasil penelitian diketahui pada kondisi awal nilai supervise klinis kepala sekolah dalam kegiatan pembelajaran diperoleh rata-rata 69,81 , pada Siklus I mengalamai peningkatan dengan rata - rata peroleh nilai pada supervise klinis sebesar 76,92 mengalami peningkatan sebesar 7,11. Pada siklus II nilai supervise klinis diperoleh rata rata 83,08. Mengalami peningkatan dari siklus I ke Siklus Il sebesar 6, 16. Dari data ini berarti terjadi peningkatan nilai supervise klinis kepala sekolah dalam kegiatan pembelajaran dari kondisi awal hingga akir siklus II sebesar $13,93 \%$.

Dari data di atas dapat disimpulkan bahwa Penerapan Supervisi Klinis Oleh Kepala Sekolah dapat Meningkatkan Kemampuan Guru Menggunakan Model Pembelajaran Kooperatif Di Sekolah Dasar Inpres Tarawaja 


semster Ganjil Tahun 2018/2019.
Berdasarkan temuan-temuan ini
disarankan beberapa hal antara
lain sebagai berikut.NBagi kepala
sekolah, hendaklah tetepa
menerapkan pelaksanaan
supervise klinis kepada guru
secara berkala, sehingga guru
selalu menyiapkan dirinya baik
dalam penyiapan perangkat
pembelajaran maupun penyiapan
dalam hal proses pemmbelajaran
dikelas. dengan
menggunakan model, metode
maupun strategi mengajar
kooperatif maupun inovatif.
Sedangkan bagi guru selalu
berinovasi dalam menggunakan
model, strategi maupun metode
pembelajaran demir untuk
meningkatkan profesionalisasi diri.

DAFTAR PUSTAKA

A.Mulyasa. 2003. Kurikulum Berbasis Kompetensi. Bandung: Remaja Rosda Karya.

\section{--oo7. Standar Kompetensi dan Sertifikasi Guru.Bandung: \\ PT.RemajaRosdakarya}

Bhoke, Wilibaldus. 2016. Pengaruh Model Pembelajaran Kooperatif Tipe Student Teama Achievement Division (STAD) dan Motivasi Belajar terhadap Hasil Belajar Matematika Siswa Kelas V SD Gugus 2 Kecamatan Bajawa Kabupaten Ngada-Flores. Jurnal IImiah Pendidikan Citra Bakti Vol 3, No 1 Maret 2016-Online Page 102112.

Ngalim Purwanto: 2006. Psikologi Pendidikan. Bandung:PT Remaja Rosdakarya.

Soetjipto dan Kosasi, Raflis. 2009. Profesi Keguruan. Jakarta: PT. Rieneka Cipta

Wahjosumidjo. 2010. Kepemimpinan Kepala Sekolah Tinjauan Teoretik dan Permasalahannya . Jakarta: PT Raja Grafindo Persada. 